\title{
Reflecting on Best Practices for Online Learning in a Post-COVID-19 World
}

\author{
Nathan Schrenk \\ Kelly Alves \\ Drew Van Dam \\ Brianne Schrenk \\ Liberty University, USA
}

\begin{abstract}
When the novel coronavirus 2019 caused many schools to immediately go online in March 2020, many instructors had significant training and experience teaching residentially but little to no experience teaching online courses. All classes were immediately converted to online, and some schools are still uncertain as to when they will return to full traditional classroom settings. Regardless of online experience, all instructors were needed to learn to adapt to online teaching immediately. This change created a need for all faculty members to receive the training and support necessary to make the online process as smooth and effective as possible. In this Best Practices perspective, we identified useful and successful practices to help students learn in the online courses. With the knowledge of data driven support and awareness of effective online teaching strategies, instructors can make the most of online teaching sessions.
\end{abstract}

Keywords: COVID-19, novel coronavirus, online teaching, asynchronous courses, distance learning, online pedagogy

Schrenk, N., Alves, K., Van Dam, D., \& Schrenk, B. (2021). Reflecting on best practices for online learning in a post-COVID-19 world. Online Learning, 25(4), 486-504.

DOI: $10.24059 /$ olj.v25i4.2460 
In the spring of 2020, when the COVID-19 pandemic spread across the world, most schools and classes were immediately converted to asynchronous online formatting (Cai et al., 2020; Cheng, 2020). At least 1,102 colleges and universities in the U.S. went online, which affected more than 14 million higher education students (CNBC, 2020). Some instructors had experience or training with online instruction and were prepared to immediately transition residential classes to online; however, an estimated $80 \%$ of instructors were not ready for this change (Marcus, 2020). This article will present concerns and considerations when teaching asynchronous classes online and will list approaches that are found to be successful.

\section{Questions and Methodology}

To investigate the transition from residential to online classes after the spread of the COVID-19, we desired to first lay a foundation using the history of online education along with investigating the ramifications the spread of COVID-19 had on education in April 2020 (Gudmundsdorttir \& Hathaway, 2020; Zhou \& Zhou, 2020). As instructors in a university that teaches online, but still faced challenges along with our students in adapting to the pandemic and its effects on our teaching, we sought to identify strategies we could use. Our work was guided by the following questions:

1. How are students and faculty impacted by availability of technology particularly in lower income areas (Chatterjee, 2018; Hall et al., 2020)?

2. What are the major challenges faced when converting synchronous classes to completely asynchronous (Picciano, 2019; Tereseviciene et al., 2020)?

3. What resources are found to be most effective for both students and faculty to promote student success (Ally, 2019; Weidlich \& Bastiaens, 2018)?

4. How can students and instructors best apply these factors to facilitate an effective transition (Bequidenhout, 2018; Radovan, 2019)?

We will report our findings from this literature-supported reflective inquiry in three parts: background, research, and application. Ideally, this can serve to not only help students, instructors, and administrators understand current research but also facilitate the development of best practices for teaching online classes (Cam et al., 2016; Watson et al., 2017). This information inform how universities support teachers when they transition from synchronous to asynchronous courses in short periods of time (Kaden, 2020; Means \& Neisler, 2021).

\section{Online Education}

\section{Background}

Picciano (2019) found that 20 million Americans were enrolled in at least one completely online course, which was an increase from 6.4 million just three years earlier. Data collected prior to the onset of COVID-19 showed that online schools and programs were growing in enrollment (Miller, 2021; Ornalles, 2019; Watson et al., 2020). Large and small public colleges, as well as proprietary schools, were showing increased enrollment in online workforce certification programs, undergraduate programs, and graduate programs (Hart et al., 2021; Ilgaz, 2019; Martin \& Bolliger, 2018). Residential courses have been shown to have limitations based on time constraints for adult learners and students with jobs (Chatterjee, 2018; Jin et al., 2019). Online programs provide equivalent opportunities to traditional in-person learning for all students regardless of age, gender, social status, etc. (Cam et al., 2016; Hall et al., 2020; Kara et al., 2019). In fact, Yarbrough (2018) found evidence that many older adult learners become more comfortable with online courses to avoid negative perceptions from younger adult classmates 
more familiar with the course material. Younger students are also showing preference towards classes that are more computer based rather than traditional delivery (McClannon et al., 2018; Ornalles, 2019). However, many schools question the equality of expectations and standards the online courses and programs can offer compared to those of traditional residential courses and programs (Cam et al., 2016; Cramp et al., 2019; Ilgaz, 2019). Maintaining the same outcomes is essential.

\section{Coronavirus Impact on Education}

In Spring 2020, many institutions were forced to immediately transition to online learning as COVID-19 quickly spread and governments were forced to eliminate large gatherings and enforce social distancing (Cheng, 2020; Connelly et al., 2020; Zhou \& Zhou, 2020). Crawford et al. (2020) examined the COVID-19 response of 20 colleges and universities around the world and found that educational structures and resources vary among different countries; however, governmental funding and endowment were shown to have the greatest impact on a school's ability to quickly transition to online learning (Hall et al., 2020; Nakamura, 2017). Regardless of timing, the change to online learning required that faculty members abruptly change their own mindsets and instructional approaches to prepare effective and engaging online lessons and develop new teaching strategies. It is essential that educational institutions promote and support faculty members in this pursuit (Bezuidenhout, 2020; Jaggars, 2021; Miller, 2019).

\section{Access and Availability}

\section{Research Perspectives}

Hall et al. (2020) found that the largest barrier for schools to initially make the decision to go online was the available technology for faculty and students to conduct class remotely. Many students did not have computers or internet access when they were not on campus (Chatterjee, 2018, Joosten et al., 2020; Osvath, 2018). Garcia et al. (2020) found that only 23.7\% of low income students had a computer at home and $7.7 \%$ did not have internet access at home; they also found that $51.3 \%$ of students had no experience using internet frequently at home. Public wireless fidelity (Wi-Fi) could offer immediate fixes for some situations, and some colleges made extended Wi-Fi hotspots available for students to use in their cars while close to the school (Crawford et al., 2020). Comcast set noncustomer home hotspots available for public use (Xfinity, 2020). However, problems still arose in that some students had no more than mobile devices (cell phones), and some faculty members (including adjunct instructors) did not have a personal computer and used classroom machines for their course technology administration (Chatterjee, 2018; Harris, 2020; Horvitz, 2017; Johnson \& Barr, 2021).

The United States Congress passed into law the Coronavirus Aid, Relief, and Economic Security (CARES) Act in March 2020 providing \$30.7 billion of additional funding for schools with discussions of up to an additional $\$ 540$ billion through the Health and Economic Recovery Omnibus Emergency Solutions (HEROES) Act (Jordan, 2020).

Jordan (2020) found that much of the CARES Act funding went to pay for meal programs, and $\$ 3$ billion went to the state governors for discretionary funds but not directly for technology. Even when schools had the technology available, the instructors had to learn hardware and software themselves as well as be prepared to work with student technology issues (Gudmendsdottir \& Hathaway, 2020). Garcia (2020) found that only 43.4\% of instructors had received software training with only $32.5 \%$ being proficient with the technology. With this lack of availability and proficiency, recommendations for some schools were to reduce class assignments or to assign "incomplete" grades for students with complications (Harris., 2020). 
Many schools created additional pass/fail grades for students to elect so online formatting would not adversely affect their GPA (Marcus, 2020). Some schools were able to find assistance through partnering with private industry (Chatterjee, 2020). An estimated $87 \%$ of Americans have a smartphone (Berry, 2015). The availability of free mobile device applications led some schools to use Open Educational Resources (OER) and Mass Open Online Courses (MOOC) (Nakamura, 2017; Hew et al., 2018; Watson et al., 2017; Zhou et al., 2020). Free of cost to students or the school, an immediate response from instructors who were accustomed to traditional teaching was to assign similar MOOCs for students or setting up OER shells which could all be accessed via mobile applications (Hew et al., 2018; Zhou et al., 2020). All individuals with cell phones or mobile devices (regardless of data plans) could connect to the school or public WiFi hotspots to utilize these tools (Chatterjee, 2018; Xfinity, 2020).

\section{Asynchronous vs. Synchronous}

Among the initial challenges for faculty was the loss of specific days and times for meetings (Crawford et al., 2020; Kessler, 2016). For some schools that had technology and video conferencing software available, some instructors opted to hold class meetings online at the regularly scheduled time (Bailey et al., 2020; Cai \& Wang, 2020).

This scheduling became a challenge after COVID-19, however, when many students with jobs were required to alter their work hours, which conflicted with the initially scheduled class times (Ilgaz, 2019; Means \& Neisler, 2021). Teaching asynchronously online created an entirely different mindset for instructors accustomed to traditional class meeting times (Jin et al., 2019; Picciano, 2019). The available research addressed some of the largest concerns for instructors new to online teaching.

\section{Online Discussion Forums}

With the expectation that quarantine allowed students to work asynchronously from home, online discussion boards became a substitute for classroom discussion on reading assignments. While many instructors may be familiar with the concept of online discussion board forums there are important precautions and actions that are essential to facilitate quality discussions (Cornell et al., 2019; McClannon et al., 2018; Selhort et al., 2017; Thomas \& Thorpe, 2019). Research shows that to effectively incorporating discussion boards requires the instructor to provide clear communication and support and to identify the specific elements that will determine the grade such as length, grammar, topics, and number of posts (McAlvage et al., 2018; Selhort et al., 2017). This communication component was similar to the directions an instructor would create for essays or short answer responses, but these directions must be stated clearly in the discussion prompt (Little et al., 2018). Bezuidenhout (2018) cautioned that like a traditional class discussion, some students may use initial comments to try to follow the gist or similar patterns instead of displaying authentic reading. This study further suggests that requiring citations and instructor interactions is an effective approach to solving this problem.

Selhort et al. (2017) discussed the importance for instructors to be active. This is not only to monitor for language, appropriate content, and preventing confrontation, but more importantly to turn posts into strands (Little et al., 2018; McClannon et al., 2018). In addition, Ally (2019) recommended that instructors not simply read a text and make a post, but to interact the same way students and an instructor would in a classroom setting. Much like a classroom discussion, Selhort et al. (2017) and Miller (2021) suggest that instructors should ask a question and follow through with scaffolding information and facilitating interactions between students to address the reading assignment. 
An additional discovery that Selhort et al. (2017) found regarding participation is the students who were found to be active in the classroom made the same number of contributions online, but surprisingly many students who were typically less active in classroom conversation showed increased activity in online comments. Speculation was that some students have a greater comfort level with digital conversation as they may commonly have conversations with friends and family via electronic devices. However, this posed the concern of student's experience with anonymity in public online forums like Reddit or Yelp where responses may be less cordial and sometimes include offensive language or content. This emphasizes the active role that instructors must play in reading comment strands and steering conversations in productive directions (Little et al., 2018).

Many common learning management systems (LMS) allow students to post videos. Zachos et al. (2018) suggested that leveraging the popularity of social media outlets, such as Instagram and TikTock and incorporating the use of student videos could increase participation in discussion boards by making them more engaging and enjoyable for students. Selhort et al. (2018) contends that when students feel engaged with the discussion forum then not only do responses increase but students check for replies more frequently and hope for larger discussion strands.

One main debate is how to effectively address late posts (Cornell et al., 2019). Much like in traditional classroom settings, if a student is unable to attend class, then no matter the quality of comment they make, the intent of discussion is lost. In a virtual setting, students will rarely look back on a previous post for new comments (Thomas \& Thorpe, 2019). McClannon et al. (2018) suggested that instructors can help by posting a closing comment to help summarize main points of the prompt. Referencing specific student posts and names can help establish a presence and encourage a positive environment for students to have unique quality replies (Tereseviciene et al., 2020).

\section{Assessment}

Newton (2020) identified that among the 340,000 online exams taken after COVID-19 forced millions of students online, fewer than $1 \%$ of students cheated; however, academic honesty remained an area of concern for many faculty members. Cramp et al. (2019) and Stack (2015) found testing to be one of the largest disputes among faculty wanting to ensure authentic and genuine test and quiz completion in asynchronous settings. Many mobile applications and types of online software have been created to help students. Many mobile applications and online programs have been developed to help students. Although many of these resources can be helpful, others can be counterproductive. MathWay and PhotoMath allow students to simply enter a problem or take a picture with a device to get detailed steps to follow as well as the final answer. Chegg Inc. offers access to over 2,600 instructor solution manuals as well as services in many subjects where students can submit problems and receive detailed answers within 24 hours. Course Hero allows students to post their own work for others and download previous assignments from other members. All these resources are among the top results of a search if students use a search engine like Google for help in a subject. These programs and others like them can be useful resources for asynchronous learning, particularly at times when instructors are unavailable; however, they are frequently abused by students (Hart et al., 2021; Kare et al., 2019). Even with the myriad of programs available that could potentially facilitate a lack of academic honesty, Cramp et al. (2019) still found similar testing results whether synchronous or asynchronous for most students. Cramp et al. (2019) also identified good strategies for testtaking, such as setting appropriate time limits, randomizing test question values, and 
randomizing the questions themselves. Some software also allows the creation of pools of questions to randomly be selected so students may or may not see the same problems on an assessment.

Many schools have testing centers, but due to COVID-19, those were closed (Hall et al., 2020). As important as it is to monitor and control a test, asynchronous classes have a challenge ensuring student authenticity (Stack, 2015). For example, Hosler (2020) listed special software that can assist: keystroke verification software like KeystrokeDNA or TypingDNA, text matching software like Turnitin, and variable testing software Test of Variables of Attention (T.O.V.A.). Although these programs can limit academic dishonesty, they can be expensive. Free video teleconferencing software such as Skype and Zoom can allow observation of the student as they test via webcam or screen share. This method offers its own complications, however. Using this strategy requires that testing times be scheduled with the instructor or proctor, which can be difficult in an asynchronous setting (Kara et al., 2019; Yarbrough, 2018). This can be timeconsuming and inconvenient for the instructor to schedule students individually, and proctors may also require additional funding.

Some schools used lockdown browsers to avoid the issue of academic dishonesty while taking a test (Cramp et al., 2019). Respondus is a well-known third-party company, and some schools use software that have it embedded. However, this can cost the school or student money as well, and some software will need to be downloaded onto the student's computer. This can cause difficulty if students need to use public computers. There are additional challenges if the students have multiple devices available, as this software will not discern students using secondary devices (Chatterjee, 2018).

Some instructors used traditional submission of scratch paper (Stack, 2015). There are free mobile applications, such as AdobeScan, that can take pictures of sheets of paper and convert the pictures into portable data formatted (PDF) files, which can then be submitted to the instructor. However, the problem with students' lack of showing work or having work that is difficult to decipher has been shown to be worse in online education (Watson et al., 2017; Weidlich \& Bastiaens, 2018). When all work is completed on electronic devices, students often neglected to write out their work or fail to take sufficient notes (Bezuidenhout, 2018;

Tereseviciene et al., 2019).

Cramp et al. (2019) performed a comprehensive review of all forms of testing from invigilation (in person, remote live, and remote recorded) to location (on campus, exam center, and remote), to format (paper, using school computer, and online bring your own device). The findings showed that the approach towards assessment is less important than the communication and reinforcement from the instructor. This study established that academic dishonesty could occur in any assessment system. Asynchronous testing requires different approaches with students working remotely, but the assessment requirements can be possible for students to complete around their schedule (Ornalles, 2019; Yarbrough, 2018). Expectations must be maintained in all testing approaches, and while academic dishonesty can occur in any setting the instructor must be cautious and strategic when planning the assessment approach (Cramp et al., 2019). When COVID-19 forced students to work online from home, there were not many options for testing. Therefore, the instructor's flexibility and knowledge of the available options benefitted student's performance best (Newton, 2020).

\section{Campus Anywhere}

One benefit of asynchronous online education is that learning can occur wherever and whenever around a student's schedule (Ally, 2018; Horvitz, 2017; Johnson \& Barr, 2021; 
Radovan, 2019). Online learning allows students to work from the convenience of their homes, while traveling, during a break at work, when they get home after work, during late night or early morning hours, or any other time that is convenient (Mehl \& Fose, 2019; Ornalles, 2019). The course structure should align with the flexibility of asynchronous instruction (Bezuidenhout, 2018; McClannon et al, 2018). Some resources can be created as direct material instruction for students, while some videos can provide students with direction to seek their own resources (Pacciano, 2019; Weidlich \& Bastiaens, 2018).

Completing online work outside of traditional business hours can also benefit the faculty (Martin \& Bolliger, 2018). Students may need less assistance during typical business hours, allowing instructors time during the day to prepare lessons and complete other work. As a result, instructors may want to be prepared to help students in the evenings and on weekends to accommodate this non-traditional schedule (Picciano, 2019; Yarbrough, 2018). Baldwin and Trespalacios (2017) and Kara et al. (2016) encouraged online instructors to no longer restrict teaching to business hours but, within reason, be prepared to work during students' available times. Many evidence-based strategies are available to assist instructors in online teaching.

\section{MOOCs}

MOOCs provide educational opportunities for students at no cost (Joonsten et al., 2020; Nakamura, 2017; Zhou \& Zhou, 2020). Considering financial complications that schools and students mentioned (Garcia, 2020), MOOCs offer a solution for faculty to provide instruction and support for students. Alone, MOOCs hold no official credit hours or certification; however, Nakamura (2017) identified these courses as options that offer a wide variety of content from trade classes to graduate level courses for any student. Hew et al. (2018) suggested that these preconstructed courses are possibly more engaging for students than traditional courses. Zhou and Zhou (2020) recognized major American universities such as Cornell and Harvard offer convenient content ranging from high school classes through doctoral level courses. Horvitz (2017) and Johnson \& Barr (2021) discussed the workforce and recreation classes designed to teach students trades such as car maintenance or basketry. MOOCs do not provide credits that can be transferred, but they can provide students a gradebook and certificate of completion for instructors to verify participation (Hew et al., 2018; Nakamura, 2017; Zhou \& Zhou, 2020).

\section{Adult Learning}

Gross \& Clark (2018) stated that $40 \%$ of all college students are 25 years of age or older and maintain employment outside of school. With COVID-19 forcing these students online, faculty should consider the needs of adult learners and non-traditional college students (Ornelles, 2019). Adult learners have very different experiences in education than traditional students (Hart et al., 2021; Jin et al., 2019). Trends and teaching approaches can change over time; Kara et al. (2019) found that many adult learners felt intimated by observing younger classmates who seemed more knowledgeable and would often become discouraged in traditional classroom settings. Online education balances the student abilities and helps students to avoid feeling disconnected (Jin et al., 2019; Yarbrough, 2018). In an online setting many of the variances among students are less obvious which reduces biases and allows all students to have more similar opportunities and experiences (Cam et al., 2016).

\section{Video Lectures}

Cheng (2020) found that when teachers familiar with synchronous classroom learning went online, a common initial plan was to turn to video lecture during the course scheduled time; these videos could be recorded and posted in the schools LMS. However, videos are often less helpful than intended and often need improvement (Bezuidenhout, 2018; Weidlich \& Bastianes, 
2018). Ally (2019) found there to be little attendance for these video lectures and few authentic views when posted into the LMS. Additionally, many of the videos were over an hour in duration. Videos found to be most viewed and helpful for students were 3 to 5 minutes and allowed students to select the specific topics where they may need additional support (Martin \& Bolliger, 2018; Watson et al., 2017). The scheduled online class time (even when the same as the originally scheduled class) were what created problems for students whose work schedules were changed due to COVID-19 (Crawford et al., 2020) as well as for students with a lack of technology (Garcia, 2020).

Bailey et al. (2020) and Jaggars (2021) found professional videos to be more helpful for students. These studies were found to have better audio and video quality and had fewer mistakes (verbiage or content) than instructor-made videos. When instructors worked from home after COVID-19, there were problems with family, pets, and other distractions from home (Cummins, 2020). One of the leaders in free online videos is Khan Academy (2020). Their videos are grouped and sequenced, are limited in duration to single topics that can be viewed individually or continuously and use hardware to provide high quality videos. Students report success and satisfaction with the Khan Academy video lecture structure. YouTube has a wide variety of videos, but presenter verification is limited, whereas Khan Academy only uses qualified and trained instructors. Therefore, instead of an instructor's initial inclination to develop their own videos, students may benefit more by leading them in the direction of quality and established videos that are already available online.

\section{Support and Strategies}

Based on the concerns and considerations for residential instructors to become effective online instructors, there is a need to identify data-driven methods that promote successful online learning strategies. Distance learning requires a different mentality than traditional pedagogy, so open dialogue will help instructors (Bezuidenhout, 2018; Osvath, 2018). In post COVID-19 education, many students are new to online learning as well, so if instructors can plan wellfounded approaches and create a positive environment, then all stakeholders can be successful in class (Cai \& Wang, 2020; Kaden, 2020).

\section{Planning and Management}

Traditional classroom administration allows time for instructors to discuss planning, structure, and expectations with the ability for students to ask questions; however, online classrooms require a different format (Baldwin \& Trespalacios, 2017; Radovan, 2019). When COVID-19 forced students to be home and no longer in the classroom these open discussions could not occur. Posting announcements in the LMS and sending emails have become essential (Kaden, 2020). Students can reply and send emails, but may not always follow through, so repetitively including detailed and thorough information is necessary (Benzuidenhout, 2018). Cheng (2020) mentioned that frequently students new to online learning may make assumptions prior to viewing detailed announcements or instructions, so multiple times per week or even daily communication can help reinforce expected requirements.

Learning Tasks and Work Plans. Many students reported a lack of success in online courses because of being behind in material rather than a lack of understanding (Ally, 2019; Picciano, 2019). In traditional classes students have a mindset of planning the day before class and reviewing in class structure and time management needed; however, online classes can allow for students to lose track of time and get behind in material (Radovan, 2019). Research suggests that providing timelines and work plans to students helps them be more successful (Bezuidenhout, 2018; Martin \& Bolliger, 2018). A dichotomy of students existed after the spread 
of COVID-19 as some students were forced into quarantine; some students rarely left home and some students' work demands increased, which complicated their schedules (Cummins, 2020). Although the reasons may have varied, many students fell behind or lost track of time during COVID-19. Some students that stayed home would lose track of days or get busy with projects around the house. Students with increased work schedules had additional struggles with time management (Robinson, 2020). Setting long-term and short-term goals in online learning is essential (Ally, 2019).

Physical and Mental Health. Physical activity is shown to have a significant impact in education (Jensen, 2020). Online learning has the potential to be challenging since learners may be more stagnant and less active than when attending classes at a school (Ally, 2019). Promoting activity will help students be more successful academically (Cheng, 2020; Cai \& Wang, 2020). Jaggars (2021) and Connelly et al. (2020) both discussed the importance of considering not only the physical health in a post COVID-19 system and the need for students to take precautions to stay safe, but also dealing with the stress of changing to online learning. Miller (2021) encouraged instructors to provide leniency as many students experience more stress and anxiety than they share with instructors. Communication can often be more important than deadlines, and this communication can allow instructors to make individualized plans for students to create a routine. This interaction with the instructors can significantly decrease stress and anxiety for students (Cai \& Wang, 2020; Connelly, 2020).

\section{Communication}

While residential classes can have discussions during multiple class meetings, online courses need to rely on digital communication (Bouchey, 2021; Weidlich \& Bastiaens, 2018; Zachos et al., 2018). This communication should not be limited to email (Zachos et al., 2018). Students should be encouraged to have their school email and LMS applications on their mobile devices with notifications, but text messaging and social media can be helpful as well and aligns with a student's comfort zone (Gudmundsdottir \& Hathaway, 2020). Cornell et al. (2019) suggested instructors have separate personal and professional accounts, which allow them to maintain appropriate, professional relationships with students. With the increased technology promotion and requirements during the COVID-19 pandemic and beyond, the notifications and use of technology-based forms of communication will promote immediate responses and clarify expectations (Robinson, 2020).

Reach Out. Considering that anxiety levels for students after COVID-19 proved to be much higher than for instructors, reaching out became more important (Chung, 2020; Kessler et al., 2016). While the instructors may have felt unprepared to go online, students experienced unprepared professors in combination with anxiety about grades and course credits (Cai et al., 2020). The instructor should be the first to engage in open communication and should frequently maintain a line of correspondence with all students (Cornell et al., 2019; McClannon et al., 2018). This connection can serve as the replacement for residential classes that meet multiple times per week (Cornell et al., 2019). Once students who struggle were identified, the instructors were positioned to consider additional (even daily) communication and schedule tutor sessions (Bezuidenhout, 2018; Martin \& Bolliger, 2018). While this might seem like an intuitive, even easy strategy, Young (2020) found that almost $20 \%$ of online learners report not having any personal communication with their instructor during a course.

An instructor's quick response time to a student's email will make a big difference regarding a student's experience in the online class (Georgiou, 2018; Radovan, 2019). When students evaluate online courses the frustration of an instructor taking too long to reply 
outnumbered all other complaints combined, and the second most common complaint was the instructor not replying to emails at all (Martin \& Bolinger, 2018). To assuage these challenges, Ally (2019) recommended replying within 48 hours and acknowledged that since instructors expect action from students, then reciprocating is an effective approach. There will be times that instructors cannot reply, but an effective strategy is for instructors to have their email and LMS application on their personal device as well (Cornell et al., 2019). The better an instructor can communicate, the more comfortable and less stressed students will be while trying to learn during COVID-19 and beyond (Young, 2020).

Increase Feedback. Classroom instructors may not have been fully aware of the value of the communication that occurs in the classroom setting, which is somewhat diminished by online instruction. This reduced communication can result in increased student stress (Young, 2020). Feedback for projects should include extensive and thorough guidance on what was correct and how to improve work. In many cases, emailing or reaching out to students directly can provide meaningful assistance that online learners may have required (Bouchey, 2021; Mehl \& Fose, 2019). This was compared to when an instructor would hand an assignment back and make a comment at that time in addition to anything written. In traditional classroom learning, students can discuss submission of work with instructions and their thoughts prior to deadlines; this can allow instructors to provide detailed feedback on items such as length or specific content that could provide higher grades (Ally, 2019). However, when instructors teaching online provide feedback on grades, they should consider time for students to adjust and resubmit assignments for a better-quality assignment (Bezuidenhout, 2018).

Work Groups. Residential students frequently created work or study groups to provide mutual support (Thomas \& Thorpe, 2019); however, finding collaborators and forming a group can be difficult after COVID-19 with quarantine (Cummins, 2020). This has always been an issue for online students. In times of emergency instruction, former residential students were also missing out on peer interactions, including discussion, dialogue, encouragement, and support (Baldwin \& Trespalacios, 2017; Thomas \& Thorpe, 2019). Cornell et al. (2019) and McClannon (2018) stated that when students have a sense of community, they can have a sense of presence. Instructors can facilitate the work groups through implementation of teleconferencing software such as Zoom and can also promote social media usage for students to communicate with one another (Zachos et al., 2018). These work groups can help students with tutoring and academic reinforcement, but also provide the encouragement and support that occurs in traditional classroom courses (Cornell et al., 2019). Using social media and communication applications, students can create pairs or peer groups and, even in quarantine, can schedule video sessions while they work (Young, 2020). Scheduled work group sessions can also pose as scheduled class time for accountability to continued progress (Robinson, 2020).

Announcements. While working remotely during COVID-19 students still needed the same frequent instruction and direction (Young, 2020). Research shows that instructors should post an announcement listing the weekly requirements at least twice a week (Baldwin \& Trespalacios, 2017; Watson et al., 2017). These announcements provided students with clear communication needed for assignments, but also serve as a reminder for students (Ally, 2019). If the announcements come by email or LMS messaging, they can open dialogue opportunities for students to reply with questions (Martin \& Bolliger, 2018).

Lectures. Residential instructors that move to online teaching often use document cameras or webcams to record a lecture they would have taught in the classroom and post the video for students (Baldwin \& Trespalacios, 2017). Prior to the pandemic, Kesslet et al. (2016) 
found that $91 \%$ of online instructors initially planned synchronous virtual meetings. However, online students did not often watch these lectures; online students seemed to prefer to be efficient and will be more prone to use Google (2020) to search keywords for individual topics individual topics they find challenging (Tereseviciene et al., 2019; Bezuidenhout, 2018). Grouping material with more videos that are shorter in length can be more effective (Watson et al., 2017). The Khan Academy (2020) videos may be more reliable and accurate than YouTube or Google videos, so guiding students to find verified resources will help (Tereseviciene et al., 2020). In a postCOVID-19 world, it is essential for students to utilize the internet for finding reliable and helpful resources (Young, 2020). Creating videos from home provides complications with background noises, poor equipment, incorrect grammar, and even material inaccuracies since teachers rarely edit or adjust fallacies the way publishers have editors that monitor multimedia (Cummings, 2020). By instructors providing easy access and direction to locate these resources, time can be more efficiently spent with other strategies and students benefit from quality videos (Cai et al., 2020; Cheng, 2020; Young, 2020).

\section{Application of Findings}

As faculty and students enter the stress and unknown of teaching and learning in a postCOVID-19 world, structure and communication are critical. Students need clear direction through instructions and announcements. The instructor needs to open individual contact early just as they would in traditional classes and have many avenues and vehicles to do so. Reciprocal communication will allow both the instructor and students to seek information when needed.

Instructors should provide students with strategies and detail best approaches. Like traditional classes in which students learn differently, professors will need a spectrum of resources available for teaching students online and need to communicate these options early when teaching online during COVID-19 quarantine. Follow-through is essential; instructors need to ensure students are not ignoring or missing the important communication details. Students will feel more confident and be more productive if they have a plan and clear direction.

Instructors need to provide thorough and swift feedback. They need to be flexible and even allow students opportunities to improve performance; assumptions cannot be made that students are being lazy or not paying attention. The traditional process of how students would ask for guidance in a classroom is very different from that of learning in a post-COVID-19 distance learning setting. If the students were confused, then leniency should be allowed, and students should have the opportunity to still show proficiency.

With students already feeling distant in communication and direction, instructors need to take actions to continue to openly communicate with students by both asking questions and reinforcing progress. Support comes from reminders along with direction. With the wealth of resources available for students, instructors need to help students find what works for them.

Students and instructors are in this together. Whether residential classrooms or online learning, an instructor's job is to see students master material. There are many plans and approaches the instructor can use to work with students individually to achieve that success.

\section{Limitations}

Many of the strategies and research presented are ubiquitous for all disciplines; however, some of the software programs and references mentioned will be specific to the subject of mathematics. Readers will still want to collaborate with colleagues and department chairs for websites and mobile applications specific to their content area. As of the completion of this paper 
in October 2020, little research had been peer-reviewed and published providing school responses to COVID-19 globally. The articles included are from China, which may differ from other countries. Much of the online pedagogy research will identify results of online and distance learning approaches that were tested prior to COVID-19 and updates were added as additional publications became available.

\section{Conclusion}

Many schools have committed to remaining online indefinitely and other schools are unsure as to what approaches work best for their student body (Crawford et al., 2020). However, all instructors may benefit from knowing good strategies for teaching online (Ally, 2019; Bezuidenhout, 2018). Concerns will continue to exist for the foreseeable future, additional considerations must be taken when utilizing distance learning (Picciano, 2019). Stress levels have increased for faculty and students alike from uncertainty and safety (Kaden, 2020). Faculty need to create a plan on how to address managing the classroom from home and need to communicate that with their students (Chung, 2020). Student instruction can be enhanced by learning and applying helpful and effective approaches for teaching asynchronous online courses (Cai et al., 2020; Cheng, 2020). 


\section{References}

Ally, M. (2019). Competency profile of the digital and online instructor in future education. International Review of Research in Open and Distributed Learning, 20(2), 302-318. https://doi.org/10.19173/irrodl.v20i2.4206

Bailey, J., Hess, F., Cerf, C., Conoway, C., El-Mekki, S., Erquiaga, D., . . White, J. (2020). A blueprint for back to school. American Enterprise Institute.

https://www.jstor.org/stable/resrep24606

Baldwin, S. J., \& Trespalacios, J. (2017). Evaluation instruments and good practices in online education. Online Learning, 21(2). https://doi.org/10.24059/olj.v21i2

Berry, M., \& Westfall, A. (2015). Dial D for distraction: The making and breaking of cell phone policies in the college classroom. College Teaching 63, 62-71.

https://doi.org/10.1080/87567555.2015.1005040

Bezuidenhout, A. (2018). Analysing the importance-competence gap of distance educators with the increased utilisation of online learning strategies in a developing world context. International Review of Research in Open and Distributed Learning, 19(3), 263-281. https://doi.org/10.19173/irrodl.v19i3.3585

Bouchey, B., Gratz, E., \& Kurland, S. (2021). Remote student support during COVID-19: Perspectives of chief online officers in higher education. Online Learning, 25(1), 28-40. https://doi.org/10.24059/olj.v25i1.2481

Cai, R., and Wang, Q. (2020). A six-step online teaching method based on protocol-guided learning during the COVID-19 epidemic: A case study of the first middle school teaching practice in Changyuan City, Henan Province, China. Insight Educational Front, 5(1), 469-480 https://doi.org/10.15354/bece.20.rp010

Cam, S. S., Yarar, G., Toraman, C., \& Erdamar, G. K. (2016). The effects of gender on the attitudes towards the computer assisted instruction: A meta-analysis. Journal of Education and Training Studies, 4(5), 250-261. https://doi.org/10.11114/jets.v4i5.1515

Chatterjee, K. (2018). Shaping the future: An online education ecosystem. Childhood Education, 94(4), 56-59. https://doi.org/10.1080/00094056.2018.1494445

Cheng, X. (2020). Challenges of "School's out, but class's on" to school education: Practical exploration of Chinese schools during the COVID-19 pandemic. Scientific Insight Educational Front, 5(2), 501-516. Doi.org/10.2139/ssrn.3565605

Chung, B., Xu, D., \& Eichhorn, S. (2018). Increasing interpersonal interactions in an online course: Does increased instructor email activity and voluntary meeting time in a physical classroom facilitate student learning? Online Learning, 22(3), 193-215. doi.org/10.24059/olj.v22i3.1322 
CNBC. (2020). How coronavirus dramatically changed college for over 14 million students. Make it. https://www.cnbc.com/2020/03/26/how-coronavirus-changed-college-for-over-14million-students.html

Conolly, C., Crepeau-Hobson Franci, Kennedy-Paine, C., \& Woitaszewski, S. (2020). Returning to school after COVID-19: Strategies for schools. National Association of School Psychologists. http://ezproxy.liberty.edu/login?url=https://search-proquestcom.ezproxy.liberty.edu/docview/2413943324?accountid=12085

Cornell, H. R., Sayman, D., \& Herron, J. (2019). Sense of community in an online graduate program. Journal of Effective Teaching in Higher Education, 2(2), 117-132.

https://jethe.org/index.php/jethe/article/view/52/25

Cramp, J., Medlin, J. F., Lake, P., \& Sharp, C. (2019). Lessons learned from implementing remotely invigilated online exams. Journal of University Teaching and Learning Practice, 16(1). https://ro.uow.edu.au/jutlp/vol16/iss1/10

Crawford, J., Butler, K., Rudolph, J., Malkawi, B., Glowatz, M., Burton, R., Magni, P., \& Lam, S (2020). COVID-19: 20 Countries' higher education intra-period digital pedagogy responses. Journal of Applied Learning \& Teaching 3(1), 1-20. https://doi.org/10.37074/jalt.2020.3.1.7

Cummins, E. (2020). Shirking form home. Vox. https://www.vox.com/thehighlight/21317485/work-from-home-coronavirus-covid-19-zoom-distraction-animal-crossing

Garcia, E., Weiss, E., \& Engdahl, L. (2020, April 17). Access to online learning amid coronavirus as far from universal, and children who are poor suffer from digital divide. Economic Policy Institute. https://www.epi.org/blog/access-to-online-learning-amid-coronavirusand-digital-divide/

Georgiou, M. (2018). Issues that revolve around the concepts of distance education and elearning. International Association for Development of the Information Society. https://eric.ed.gov/?id=ED590272

Gross, N., \& Clark, K. (2020). Adult college students; The undercovered 6.6 million. Educational Writers Association. https://www.ewa.org/blog-higher-ed-beat/adult-collegestudents-undercovered-66 million\#: :text=In\%20fact $\% 2 \mathrm{C} \% 20$ thanks $\% 20$ to $\% 20$ economic,enrolled $\% 20 \mathrm{in} \% 20 \mathrm{higher} \% 20 \mathrm{ed}$ ucation\%20currently.

Gudmundsdottir, G. B., \& Hathaway, D. M. (2020). "We always make it work": Teachers' agency in the time of crisis. Journal of Technology and Teacher Education, 28(2), 239. http://ezproxy.liberty.edu/login?url=https://search-proquestcom.ezproxy.liberty.edu/docview/2410497208? accountid=12085 
Hall, J., Roman, C., Jovel-Arias, C., \& Young, C. (2020). Pre-service teachers examine digital equity amidst schools' COVID-19 responses. Journal of Technology and Teacher Education, 28(2), 435. http://ezproxy.liberty.edu/login?url=https://search-proquestcom.ezproxy.liberty.edu/docview/2410497004? accountid=12085

Harris, D. N. (2020). A broad strategy for schools during the COVID-19 pandemic. The Brookings Institution. http://ezproxy.liberty.edu/login?url=https://search-proquestcom.ezproxy.liberty.edu/docview/2383693604? accountid=12085

Hart, C. M. D., Xu, D., Hill, M., \& Alonso, E. (2021). COVID-19 and community college instructional responses. Online Learning, 25(1), 41-69. https://doi.org/10.24059/olj.v25i1.2568

Hew, K. F., Qiao, C., \& Tang, Y. (2018). Understanding student engagement in large-scale open online courses: A machine learning facilitated analysis of student's reflections in 18 highly rated MOOCs. International Review of Research in Open and Distributed Learning, 19(3), 69-93. https://doi.org/10.19173/irrodl.v19i3.3596

Horvitz, B. S. (2017). Future directions for research on online technical education. Community College Journal of Research and Practice, 41(6), 381-385. https://doi.org/10.1080/10668926.2016.1270241

Hosler, A. (2020). How schools are preventing students from cheating online. The Degree360. https://www.onlinedegrees.com/degree360/student-focus/fighting-back-against-virtualcheaters.html

Ilgaz, H. (2019). Adult learners' participation in a blended learning environment: A case study on imposed pace learning. Malaysian Online Journal of Educational Technology, 7(4), 15-29. https://eric.ed.gov/?id=EJ1233902

Jaggars, A. (2021). Introduction to the special issue on the COVID-19 emergency transition to remote learning. Online Learning, 25(1), 1-7. http://dx.doi.org/10.24059/olj.v25i1.2692

Jin, B., Kim, J., \& Baumgartner, L. M. (2019). Informal learning of older adults in using mobile devices: A review of the literature. Adult Education Quarterly: A Journal of Research and Theory, 69(2), 120-141. https://doi.org/10.1177/0741713619834726

Jensen Learning Corporation (2020). Jensen Learning. https://www.jensenlearning.com/

Johnson, J. E., \& Barr, N. B. Moving hands-on mechanical engineering experiences online: Course redesigns and student perspectives. Online Learning, 25(1), 209-219. https://doi.org/10.24059/olj.v25i1.2465

Jones, H. (2020). TikTok's popularity surges amid COVID-19 pandemic. The Daily Campus. https://www.smudailycampus.com/ae/tiktoks-popularity-surges-amid-covid-19-pandemic. 
Joosten, T., Lee-McCarthy, K., Harness, L., Paulus, R., \& Online Learning Consortium (OLC). (2020). Digital learning innovation trends. Online Learning Consortium. https://eric.ed.gov/contentdelivery/servlet/ERICServlet?accno=ED603277

Jordan, P. (2020). What congressional funding means for K-12 schools. Future Ed. https://www.future-ed.org/what-congressional-covid-funding-means-for-k-12-schools/

Kaden, U. (2020). COVID-19 school closure-related changes to the professional life of a K-12 teacher. Education Sciences, 10(6), 165.

http://dx.doi.org.ezproxy.liberty.edu/10.3390/educsci10060165

Kara, M., Erdogdu, F., Kokoç, M., \& Cagiltay, K. (2019). Challenges faced by adult learners in online distance education: A literature review. Open Praxis, 11(1), 5-22. https://www.learntechlib.org/p/208075/.

Kessler, G. (2016). What can we learn from our colleagues? A framework for virtual classroom Little, C. W., Clark, J. C., Tani, N. E., \& Connor, C. M. (2018). Improving writing skills through technology-based instruction: A meta-analysis. Review of Education, 6(2), 183-201. https://doi.org/10.1002/rev3.3114

Liu, S., Yang, L., Zhang, C., \& Xiang, Y. (2020). Online mental health service in china during the COVID-19 outbreak. Lancet Psychiatry, 7(4), 17-18. doi.org/10.1016/S22150366(20)30077-8

Marcus, J. (2020). Pass/fail grades may help student during the COVID-19 crisis but could cost them later. The Hechinger Report. https://www.pbs.org/newshour/education/pass-fail-gradesmay-help-students-during-the-covid-19-crisis-but-could-cost-them-later

Marcus, J. (2020). Will this semester forever alter college? No, but some virtual tolls will stick around. The Hechinger Report. https://hechingerreport.org/will-this-semester-forever-altercollege-no-but-some-virtual-tools-will-stick-around/

Martin, F., \& Bolliger, D. U. (2018). Engagement matters: Student perceptions on the importance of engagement strategies in the online learning environment. Online Learning, 22(1), 205-222. http://doi.org/10.24059/olj.v22i1.1092

McAlvage, K., \& Rice, M. (2018). Access and accessibility in online learning: Issues in higher education and $\mathrm{K}-12$ contexts. From "OLC Outlook: An environmental scan of the digital learning landscape." Online Learning Consortium. https://eric.ed.gov/contentdelivery/servlet/ERICServlet?accno=ED593920

McClannon, T. W., Cheney, A. W., Bolt, L. L., \& Terry, K. P. (2018). Predicting sense of presence and sense of community in immersive online learning environments. Online Learning, 22(4), 141-159. https://olj.onlinelearningconsortium.org/index.php/olj/index 
Means, B., \& Neisler, J. (2021). Teaching and learning in the time of COVID: The student perspective. Online Learning, 25(1), 8-27. https://doi.org/10.24059/olj.v25i1.2496

Mehl, M., \& Fose, L. (2016). Digital academic revolution mentorship competency: \#1 The Declaration-Mentoring the process of learning with screencast assessment-Plugging into students' digital DNA a decade later. Online Learning Consortium.

https://eric.ed.gov/contentdelivery/servlet/ERICServlet?accno=ED570939

Miller, G., Benke, M., Chaloux, B., Ragan, L. C., Schroeder, R., Smutz, W., Swan, K., \& Online Learning Consortium (OLC). (2019). Leading the E-Learning Transformation of Higher Education: Meeting the Challenges of Technology and Distance Education. Online Learning Consortium. https://onlinelearningconsortium.org/book/leading-e-learning-transformationhigher-education-meeting-challenges-technology-distance-education/

Miller, K. E. (2021). A light in students' lives: K-12 teachers' experiences (re)building caring relationships during remote learning. Online Learning, 25(1), 115-134.

https://doi.org/10.24059/olj.v25i1.2486

Nakamura, M. (2017). The state of distance education in Japan. Quarterly Review of Distance Education, 18(3), 75-87.

https://books.google.com/books?hl=en\&lr=\&id=4g9bDwAAQBAJ\&oi=fnd\&pg=PA75\&dq=The +state+of+distance+education+in+Japan.+\&ots=iZ90O-

VqX7\&sig=rqxnhhSOe4BFA1dtOUoybdoFV_4\#v=onepage \&q=The\%20state\%20of\%20distanc e\%20education\%20in\%20Japan.\&f=false

Newton, D. (2020). Another problem with shifting education online: cheating. The Hechinger Report. https://hechingerreport.org/another-problem-with-shifting-education-online-cheating/

Ornelles, C., Ray, A. B., \& Wells, J. C. (2019). Designing online courses in teacher education to enhance adult learner engagement. International Journal of Teaching and Learning in Higher Education, 31(3), 547-557. http://www.isetl.org/ijtlhe

Osvath, C. (2018). Ready learner one: Creating an oasis for virtual/online education. Journal of Language and Literacy Education, 14(1). http://jolle.coe.uga.edu

Picciano, A. G. (2019). Artificial intelligence and the academy's loss of purpose. Online Learning, 23(3), 270-284. http://doi.org/10.24059/olj.v23i3.2023

Radovan, M. (2019). Should I stay, or should I go? Revisiting student retention models in distance education. Turkish Online Journal of Distance Education, 20(3), 29-40. http://doi.org/10.17718/tojde.598211

Respondus. (2020). Respondus: Assessment tools for learning systems. Respondus, Inc. https://web.respondus.com/ 
Robinson, B. (2020). 9 tips to be productive when working at home during COVID-19. Forbes. https://www.forbes.com/sites/bryanrobinson/2020/03/14/9-tips-to-be-productive-when-workingat-home-during-covid-19/\#1b1003635a38

Selhorst, A. L., Klein, E., \& Harrison, J. (2017). Cohort-specific online discussion experiences: A collaborative and multidisciplinary approach to improving student learning. Contemporary Issues in Education Research, 10(4), 241-254. https://doi.org/10.19030/cier.v10i4.10038

Stack, S. (2015). Learning outcomes in an online vs traditional course. International Journal for the Scholarship of Teaching and Learning, 9(1). http://doi.org/10.20429/ijsotl.2015.090105

Tereseviciene, M., Trepule, E., Dauksiene, E., Tamoliune, G., \& Costa, N. (2020). Are universities ready to recognize open online learning? International Education Studies, 13(2), 2132. https://doi.org/10.5539/ies.v13n2p21

Thomas, G., \& Thorpe, S. (2019). Enhancing the facilitation of online groups in higher education: A review of the literature on face-to-face and online group-facilitation. Interactive Learning Environments, 27(1), 62-71.

http://dx.doi.org.ezproxy.liberty.edu/10.1080/10494820.2018.1451897

Watson, F. F., Castano Bishop, M., \& Ferdinand-James, D. (2017). Instructional strategies to help online students learn: Feedback from online students. TechTrends: Linking Research and Practice to Improve Learning, 61(5), 420-427. http://dx.doi.org.ezproxy.liberty.edu/10.1007/s11528-017-0216-y

Weidlich, J., \& Bastiaens, T. J. (2018). Technology matters - The impact of transactional distance on satisfaction in online distance learning. International Review of Research in Open and Distributed Learning, 19(3), 222-242. https://doi.org/10.19173/irrodl.v19i3.3417

Xfinity. (2020). Zfinity WIFI hotspot access opens nationwide in response to coronavirus. Xfinity. https://www.xfinity.com/support/articles/open-xfinity-WiFi-hotspots

Yarbrough, J. R. (2018). Adapting adult learning theory to support innovative, advanced, online learning-WVMD model. Research in Higher Education Journal, 35. https://eric.ed.gov/contentdelivery/servlet/ERICServlet?accno=EJ1194405

Young, J. (2020). Coronavirus has led to a rush of online teaching. Here is some advice for newly remote instructors. EdSurge. https://www.edsurge.com/news/2020-03-11-coronavirus-hasled-to-a-rush-of-online-teaching-here-s-some-advice-for-newly-remote-instructors

Zachos, G., Paraskevopoulou-Kollia, E.-A., \& Anagnostopoulos, I. (2018). Social media use in higher education: A review. Education Sciences, 8.

https://eric.ed.gov/contentdelivery/servlet/ERICServlet?accno=EJ1201119 
Zhou, L., Wu, S., Zhou, M., \& Li, F. (2020). "School's Out, But Class's On,” the largest online education in the world today: Taking China's practical exploration during the COVID-19

epidemic prevention and control as an example. Best Evidence of Chinese Education 4(2), 501519. https://doi.org/10.15354/bece.20.ar023 